\section{Application of a diathermic dilator for negotiating near-total antropyloric strictures}

Three patients with caustic substanceinduced near-total antropyloric obstruction with recurrent vomiting were found to have a totally blocked antropyloric region with no flow of contrast distally ( $\bullet$ Fig. 1). Patient characteristics, the treatment provided, and the outcome are summarized in $\bullet$ Table 1.

After the patient had given informed consent, esophagogastroscopy was carried out with the patient under conscious sedation. The site of narrowing was identified as a dimple or depression. Attempts were made to pass a 6-8-mm wire-guided, through-the-scope balloon dilator (CRE; Boston Scientific Corp., Natick, Massachusetts, USA) into the duodenum. When this failed, it was followed by passing a hydrophilic 0.025-inch guidewire (Visiglide; Terumo Corp., Shibuya-ku, Tokyo, Japan) under fluoroscopy. A 6-Fr wire-guided coaxial diathermic dilator (Cysto-GastroSet; Endo-Flex GmbH, Voerde, Germany) was threaded over the guidewire under fluoroscopic guidance to the level of the stricture. It was used to traverse the cicatrized segment step by step by applying an intermittent diathermy current (cut mode, 40W, ERBE electrosurgical unit (ERBE USA Inc., Marietta, Georgia, USA) until the dilator passed through the entire length of the stricture ( Video 1 ). Subsequent dilations were carried out in an incremental manner, ranging from $6 \mathrm{~mm}$ to $15 \mathrm{~mm}$, with wire-guided through-thescope balloon dilators twice weekly as described previously, with a close watch for complications [1]. The patients were followed up periodically for 12 months and then imaging was repeated ( $\bullet$ Fig. 1 ). Ingestion of caustic substances leads to gastric cicatrization and gastric outlet obstruction in $36 \%-44 \%$ of patients [2-4]. All three patients in this report had neartotal antropyloric obstruction that was negotiated using a coaxial diathermy dilator followed by balloon dilation. To the best of our knowledge, this is the first re- port to describe the use of this technique in patients with caustic-induced gastric outlet obstruction. A review of the literature found that a similar diathermy catheter has been used to dilate tight bile duct and pancreatic duct strictures [5].

In conclusion, our case series describes for the first time the application of a coaxial diathermy dilator for the management of near-total gastric outlet obstruction.

Endoscopy_UCTN_Code_TTT_1AO_2AH

\section{Competing interests: None}

\section{Pradeep Siddappa ${ }^{1}$, Yalaka Rami Reddy $^{1}$, Pankaj Gupta ${ }^{2}$, Ajay Gulati ${ }^{2}$, Vikas Gupta ${ }^{3}$, Saroj Kant Sinha ${ }^{1}$, Rakesh Kochhar ${ }^{1}$}

${ }^{1}$ Department of Gastroenterology, Postgraduate Institute of Medical Education and Research, Chandigarh, India

2 Department of Radiodiagnosis, Postgraduate Institute of Medical Education and Research, Chandigarh, India ${ }^{3}$ Department of Surgical Gastroenterology, Postgraduate Institute of Medical Education and Research, Chandigarh, India
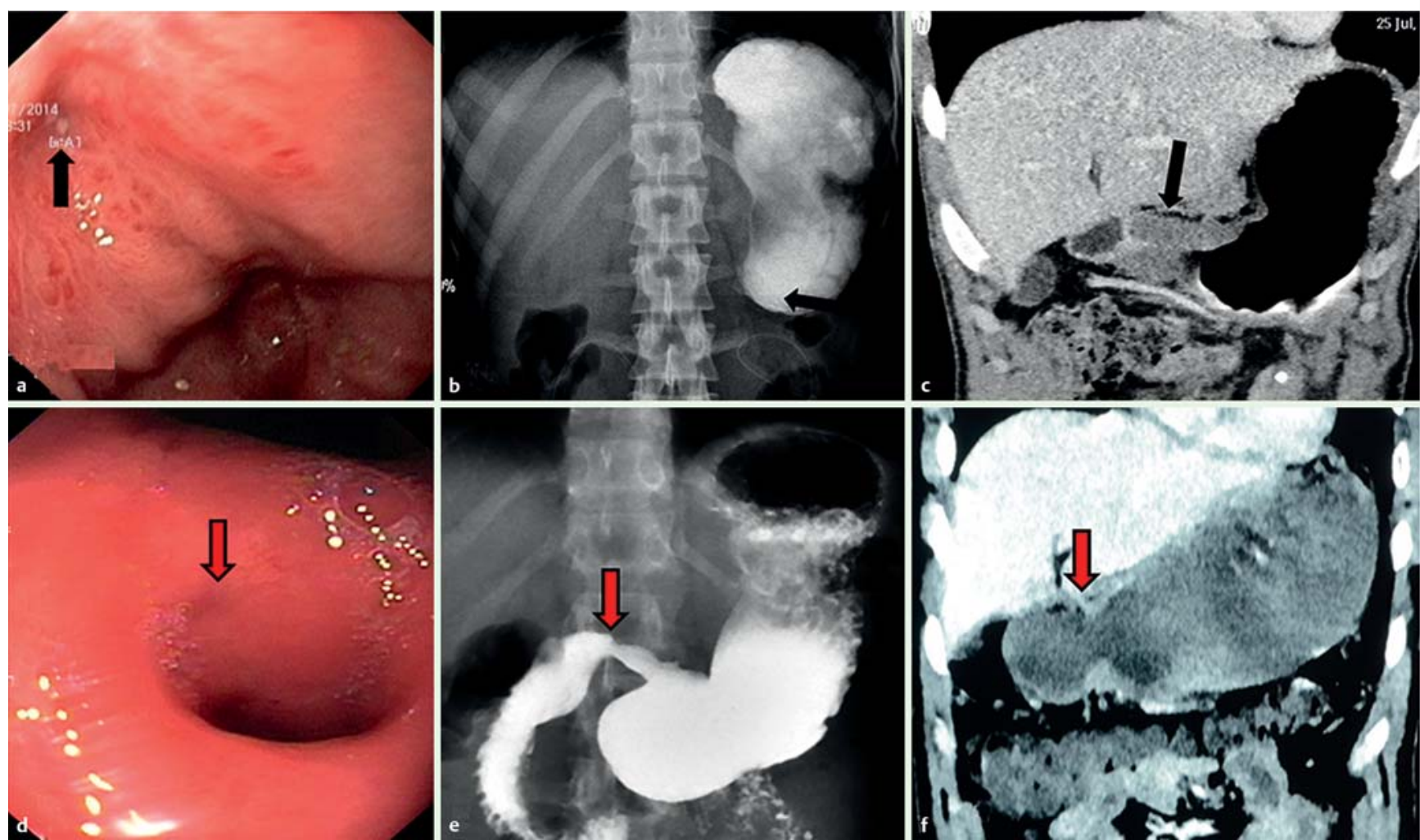

Fig. 1 a-c Complete gastric outlet obstruction (black arrow) visualized by: a endoscopy; $\mathbf{b}$ barium study; and c computed tomography (CT). $\mathbf{d}$ - e The opened up pyloric orifice following dilation (red arrow) visualized by: $\mathbf{d}$ endoscopy; e barium study; and $\mathbf{f}$ CT. 
Table 1 Caustic substance-induced near-total antropyloric obstruction treated with diathermic dilation: demographic details, characteristics, endoscopic findings, and outcomes of three patients.

\begin{tabular}{|c|c|c|c|}
\hline & Patient 1 & Patient 2 & Patient 3 \\
\hline Age, years & 21 & 28 & 18 \\
\hline Sex & Male & Male & Female \\
\hline Caustic substance & Sulphuric acid & Sulphuric acid & Nitric acid \\
\hline $\begin{array}{l}\text { Interval to presentation } \\
\text { after acid ingestion, weeks }\end{array}$ & 14 & 10 & 4 \\
\hline Symptoms & $\begin{array}{l}\text { Vomiting, weight } \\
\text { loss }\end{array}$ & $\begin{array}{l}\text { Dysphagia, vomit- } \\
\text { ing,weight loss }\end{array}$ & $\begin{array}{l}\text { Vomiting, weight } \\
\text { loss }\end{array}$ \\
\hline Site of involvement & Antropyloric region & Antropyloric region & Antropyloric region \\
\hline $\begin{array}{l}\text { Associated ulceration } \\
\text { at first dilation }\end{array}$ & Absent & Healing ulcer & Healing ulcer \\
\hline $\begin{array}{l}\text { Associated esophageal } \\
\text { stricture }\end{array}$ & No & Yes & No \\
\hline \multicolumn{4}{|l|}{ CECT abdomen } \\
\hline Stricture length, mm & 30 & 16 & 17 \\
\hline Wall thickness, mm & 10 & 9 & 8 \\
\hline First dilation & $\begin{array}{l}4 \text { mm (Hurricane } \\
\text { balloon; Boston } \\
\text { Scientific Corp., } \\
\text { Marlborough, } \\
\text { Massachusetts, USA) }\end{array}$ & $\begin{array}{l}4 \mathrm{~mm} \text { (Hurricane } \\
\text { balloon; Boston } \\
\text { Scientific Corp., } \\
\text { Marlborough, } \\
\text { Massachusetts USA) }\end{array}$ & $\begin{array}{l}6 \mathrm{~mm} \text { (CRE balloon; } \\
\text { Boston Scientific } \\
\text { Corp., Marlborough, } \\
\text { Massachusetts USA) }\end{array}$ \\
\hline Dilations to reach $15 \mathrm{~mm}, \mathrm{n}$ & 9 & 5 & 10 \\
\hline $\begin{array}{l}\text { Intralesional steroid } \\
\text { injections, n }\end{array}$ & 8 & 4 & 10 \\
\hline Follow-up, months & 12 & 11 & 10 \\
\hline Outcome & Successful & Successful & Successful \\
\hline Complications & None & None & None \\
\hline
\end{tabular}

CECT, contrast-enhanced computed tomography.

\section{References}

1 Kochhar R, Poornachandra KS, Dutta U et al. Early endoscopic balloon dilation in caustic-induced gastric injury. Gastrointest Endosc 2010; 71: 737-744

2 Zargar SA, Kochhar R, Nagi B et al. Ingestion of corrosive acids. Spectrum of injury to upper gastrointestinal tract and natural history. Gastroenterology 1989; 97: 702 - 707

3 Zargar SA, Kochhar R, Nagi B et al. Ingestion of strong corrosive alkalis: spectrum of injury to upper gastrointestinal tract and natural history. Am J Gastroenterol 1992; 87: 337 341

4 Chaudhary A, Puri AS, Dhar P et al. Elective surgery for corrosive-induced gastric injury. World J Surg 1996; 20: 703 -706

5 Kawakami H, Kuwatani M, Kawakubo Ket al. Transpapillary dilation of refractory severe biliary stricture or main pancreatic duct by using a wire-guided diathermic dilator. Gastrointest Endosc 2014; 79: 338 -343

\section{Video 1}

(i)

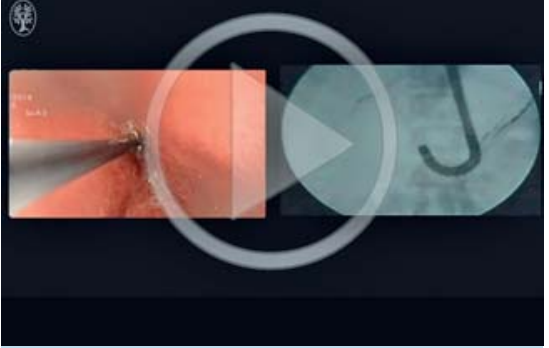

Diathermic dilation of near-total antropyloric stricture. Endoscopic view of the procedure (left) and the corresponding fluoroscopic image (right). After placement of the guidewire across the stricture site deep into the duodenum, the diathermic dilator was negotiated over the guidewire through the entire length of the stricture. This was followed by balloon dilation of the tract.

\section{Bibliography}

DOI http://dx.doi.org/

10.1055/s-0042-118453

Endoscopy 2016; 48: E365-E366

(c) Georg Thieme Verlag KG

Stuttgart · New York

ISSN 0013-726X

\section{Corresponding author \\ Rakesh Kochhar, MD}

Department of Gastroenterology

Postgraduate Institute of Medical Education

and Research (PGIMER)

Chandigarh 160012

India

Fax: +91-172-2744401

dr_kochhar@hotmail.com 